\title{
Prevalence of Staphylococcus spp. nasal colonization among doctors of podiatric medicine and associated risk factors in Spain
}

Sheila de Benito ${ }^{1}$, Luis Alou ${ }^{2 *}$ (D, Ricardo Becerro-de-Bengoa-Vallejo ${ }^{3}$, Marta Elena Losa-Iglesias', María Luisa Gómez-Lus², Luis Collado ${ }^{4}$ and David Sevillano²

\begin{abstract}
Background: This study aimed to estimate the prevalence of methicillin-susceptible and -resistant Staphylococcus aureus (MSSA and MRSA) and methicillin-resistant Staphylococcus epidermidis (MRSE) nasopharyngeal carriage among Doctors of Podiatric Medicine (Podiatrists) and to determine the potential risk factors.

Methods: A cross-sectional study was carried out in 2016-2017 among 239 podiatrists in Spain. The presence of MSSA, MRSA, and MRSE was determined by microbiological analysis of nasal exudate and antimicrobial susceptibility was determined. Each podiatrist completed a questionnaire. The questionnaire comprised various parameters such as sex, age, podiatry experience duration, underlying diseases, prior antibiotic treatment, hospitalization during the last year, and use of a protective mask, an aspiration system, or gloves.

Results: The prevalence of MSSA, MRSA, and MRSE was 23.0\%, 1.3\%, and 23.8\%, respectively. The MSSA prevalence was higher among podiatrists who did not use an aspiration system (32.3\%) compared to those who did (19.3\%; $p=0.0305)$, and among podiatrists with respiratory diseases (36.8\%) compared to those without (20.8\%; $p=0.0272$ ). The MRSE prevalence was higher among men (33.7\%) compared to women (8.6\%; $p=0.0089)$, podiatrists aged $\geq 50$ (38.5\%) compared to $\leq 35$ (17.8\%; $p=0.0101)$, and podiatrists with $\geq 15$ (39.3\%) compared to $\leq 5$ years of podiatry experience $(12.5 \% ; p=0.0015)$. Among the $S$. aureus strains, $84.5 \%$ were resistant to penicillin, $22.4 \%$ to erythromycin, $20.7 \%$ to clindamycin, and $12.7 \%$ to mupirocin. The MRSE strains were resistant to penicillin (93.0\%), erythromycin (78.9\%), and mupirocin (73.7\%).
\end{abstract}

Conclusions: The prevalence of S. aureus and S. epidermidis nasal carriage is low among Spanish podiatrists compared to other health professionals.

Keywords: Staphylococcus aureus, Staphylococcus epidermidis, Nasal carriage, Podiatrists, Methicillin

\section{Background}

Humans are a natural reservoir of Staphylococcus aureus [1]. The nasal cavity is the main reservoir, but $S$. aureus can colonize other areas of the body such as the skin, perineal region, and pharynx [2]. Studies have shown that there are three types of nasal carriers among healthy individuals: $20 \%$ are persistent carriers (range $12-30 \%$ ),

\footnotetext{
*Correspondence: luisalou@ucm.es

${ }^{2}$ Area de Microbiología, Facultad de Medicina, Universidad Complutense de Madrid, Madrid, Spain

Full list of author information is available at the end of the article
}

$30 \%$ are intermittent carriers $(16-70 \%)$, and 50\% (16$69 \%)$ are non-carriers [2, 3].

The prevalence of $S$. aureus nasal carriage varies by country, profession, and demographic group. In the general population, values range from $17.8 \%$ to $21.6 \%$ in European countries $[4,5]$ to a prevalence of $31.6 \%$ in the US [6]. A higher prevalence of $S$. aureus among health professionals has been observed, with values of $52 \%$ among physiotherapists [7], 36-66\% among nurses [8, 9], and $30.6 \%$ among pediatricians [10], but the prevalence in Doctors of Podiatric Medicine (Podiatrists) as 
members of the surgical and medical team has not been described yet in any country. There are also specific demographic groups that have higher percentages of nasal carriers. Risk factors are Caucasian ethnicity, male sex [11], advanced age [12] and use of hormonal contraceptives [13]. Additional factors include medical conditions such as insulin-dependent and -independent diabetes [14], patients undergoing hemodialysis [15], HIV [16], people with obesity [17] and patients with skin infections due to $S$. aureus or diseases of the skin [18].

Being a nasal carrier of $S$. aureus has been identified as a risk factor for the development of nosocomial and community-acquired staphylococcal infections, as it provides a reservoir from which bacteria can spread when the host's defenses are compromised [19].

$S$. aureus is one of the most common and clinically significant pathogens, causing a broad spectrum of nosocomial and community-acquired infection. It has the capacity to cause skin and soft tissue infections, osteoarticular infections, and serious systemic infections such as bacteremia and endocarditis. S. aureus is the second most common cause of bacteremia and the most common cause of nosocomial bacteremia in Europe [20].

The variability of $S$. aureus, its rapid adaptive response to environmental changes, and its continuous acquisition of antibiotic resistance factors have made it a common resident in hospitals, where it causes multiresistance problems, which can occasionally be considerable. Although the term "methicillin resistance" implies resistance to $\beta$-lactam derivatives, methicillinresistant $S$. aureus (MRSA) strains generally also have resistance to other groups of antibiotics. Via several mechanisms, these isolates can have resistance to chloramphenicol, tetracyclines, macrolides, lincosamines, aminoglycosides, and even quinolones, with MRSA outbreaks being increasingly reported [21].

$S$. epidermidis used to be considered a commensal microorganism. However, nowadays, it is considered an important opportunistic pathogen, producing a great variety of infections of varying severity and acting as a significant agent in medical implant infections. In addition, it is considered a potential reservoir of resistance genes for pathogenic bacteria, such as $S$. aureus, increasing the potential of $S$. aureus to colonize, survive during infection, and resist antibiotic treatment, which are important features of MRSA [22].

The objective of this study was to estimate the prevalence of nasal carriage of methicillin-susceptible and -resistant $S$. aureus (MSSA and MRSA) and methicillinresistant S. epidermidis (MRSE) among podiatrists in Spain (Europe), to identify the possible risk factors for colonization of both bacteria in this population, and to determine the levels of antibiotic susceptibility among the isolates.

\section{Methods}

The study was a cross-sectional study according to the STROBE statement involving 239 active podiatrists from all the states of Spain. Nasal exudate sample collection and processing were carried out between September 2016 and February 2017 in the Microbiology Department of the Complutense University of Madrid. The samples were collected after the podiatrists signed an informed consent form and completed a supplemental questionnaire.

The dichotomous dependent variables studied were the $S$. aureus and MRSE carriage status, as well as the status of co-colonization by both bacteria. The independent variables were sex, age, years of podiatry experience, underlying disease (diabetes, respiratory disease, immunosuppressive disease, and infectious disease), antibiotic therapy prior to sampling, hospitalization during the previous year, and use of a respiration mask, aspiration system, and gloves.

\section{Sample size}

The sample size was calculated with software from Unidad de Epidemiología Clínica y Bioestadística, Complexo Hospitalario Universitario de A Coruña, Universidade A Coruña (www.fisterra.com). The calculations were based on the total population living in Spain, which amounted to 42,104,557 adults on January 1, 2017. (http://www.ine.es). It was determined that, based a desired power of $80 \%$ with a $\beta$ level of $20 \%$, and a precision of $3 \%$ with an $\alpha$ level of 0.05 , with a confidence interval of $95 \%$, for a proportion of $50 \%$, assuming a loss of $15 \%$, at least 239 participants were included in the study.

\section{Sample collection, processing, and antimicrobial testing}

Samples were obtained from the front of the nostrils of each individual using a sterile swab, rotating it gently in one of the nasal cavities at least five times. The nasal swabs were streaked in two chromogenic culture media. The first was selective for the isolation of strains in the Staphylococcus genus and differential for S. aureus, i.e., CHROMagar Staph aureus medium (Becton Dickinson, Sparks, MD), and the second was for the identification of MRSA, i.e., CHROMagar MRSA medium (Becton Dickinson, Sparks, MD) with methicillin. If colonies were observed in the culture media, we used biochemical tests (mannitol agar, coagulase, polymixin B disc, and pyrrolidonyl aminopeptidase test (Becton Dickinson, Sparks, MD) to confirm and identify the strains.

An antimicrobial susceptibility analysis was performed using the agar disk-diffusion method, following the indications and interpretation criteria of the Clinical \& Laboratory Standards Institute [23]. The antibiotics used to perform the antibiogram were clindamycin $(2 \mu \mathrm{g})$, erythromycin $(15 \mu \mathrm{g})$, penicillin $(10 \mu \mathrm{g})$, chloramphenicol $(30 \mu \mathrm{g})$, vancomycin $(30 \mu \mathrm{g})$, mupirocin $(5 \mu \mathrm{g})$, 
rifampicin $(5 \mu \mathrm{g})$, tetracycline $(30 \mu \mathrm{g})$, ciprofloxacin $(5 \mu \mathrm{g})$, gentamicin $(10 \mu \mathrm{g})$, cefoxitin $(30 \mu \mathrm{g})$, linezolid (30 $\mu \mathrm{g})$, and trimethoprim/sulfamethoxazole (23.75/ $1.25 \mu \mathrm{g})$ (cotrimoxazole). Erythromycin and clindamycin discs were assessed together to detect inducible macrolidelincosamide streptogramin B (iMLS $\mathrm{B}$ ) phenotype.

\section{Statistical analysis}

We used the non-parametric Mann-Whitney U test or the independent $\mathrm{t}$-test to establish whether there were differences between groups. The chi square test was used to analyze the categorical variables. The data was analyzed using SPSS version 19 (IBM Corp., Armonk, NY, US). The level of significance was set at $p<0.05$.

\section{Results}

A total of 239 samples were analyzed. The mean age was $33.3 \pm 8.5$ years; $65 \%(115 / 239)$ of the subjects were women; and the mean number of years of podiatry experience was $9.9 \pm 7.7$.
The prevalence of $S$. aureus carriers among the podiatrists was $24.3 \%(58 / 239)$, of which $23 \%(55 / 239)$ were MSSA carriers and $1.3 \%(3 / 239)$ were MRSA carriers.

Table 1 shows the participants' characteristics and the results of the independent analyses of $S$. aureus and $S$. epidermidis carriers.

Although no significant differences were observed, MSSA was found to be more common in men (30.1\%; $25 / 83$ ) than women (19.2\%; 33/171). In addition, it was more common in older subjects, with a $21 \%(33 / 157)$ prevalence among podiatrists aged $\leq 35$ years vs. $38.5 \%$ $(5 / 13)$ among podiatrists aged $\geq 50$ years. Moreover, it was more common in subjects with more podiatry experience, with a $21.3 \%(17 / 80)$ prevalence among podiatrists with $\leq 5$ years of experience vs. $29.8 \%(17 / 56)$ among podiatrists with $\geq 15$ years of experience.

Regarding the use of protective measures, we found a higher prevalence of MSSA among podiatrists who did not use an aspiration system in their usual work practice (32.3\%; 22/68) compared to those who did (19.3\%; 33/ 171) ( $p=0.0305)$. Regarding concomitant diseases, a significantly higher prevalence was observed among

Table 1 Results of the analysis of S. aureus and S. epidermidis carriers among podiatrists

\begin{tabular}{|c|c|c|c|c|c|c|c|c|c|c|c|}
\hline \multirow[t]{3}{*}{ Variable } & \multirow[t]{3}{*}{ Category } & \multirow{3}{*}{$\begin{array}{l}N \text { total } \\
(\%)\end{array}$} & \multicolumn{6}{|c|}{ S. aureus } & \multicolumn{3}{|c|}{ S. epidermidis } \\
\hline & & & \multicolumn{2}{|c|}{ MSSA } & \multirow[t]{2}{*}{$P$} & \multicolumn{2}{|c|}{ MRSA } & \multirow[t]{2}{*}{$P$} & \multicolumn{2}{|c|}{ MRSE } & \multirow[t]{2}{*}{$P$} \\
\hline & & & $\mathrm{N}$ & $\%$ & & $\mathrm{~N}$ & $\%$ & & $\mathrm{~N}$ & $\%$ & \\
\hline \multirow[t]{2}{*}{ SEX } & Female & $156(65)$ & 30 & 19.2 & & 2 & 1.2 & & 29 & 8.6 & \\
\hline & Male & $83(35)$ & 25 & 30.1 & 0.0569 & 1 & 1.3 & 0.9593 & 28 & 33.7 & 0.0089 \\
\hline \multirow[t]{3}{*}{ AGE } & $\leq 35$ & $157(65.7)$ & 33 & 21.0 & & 1 & 0.7 & & 28 & 17.8 & \\
\hline & 36 to 49 & $69(28.9)$ & 17 & 24.6 & & 2 & 3.9 & & 24 & 34.7 & \\
\hline & $\geq 50$ & $13(5.4)$ & 5 & 38.5 & 0.3318 & 0 & 0.0 & 0.3408 & 5 & 38.5 & 0.0101 \\
\hline \multirow[t]{3}{*}{ Years of Podiatry Experience } & $\leq 5$ & $80(33.5)$ & 17 & 21.3 & & 1 & 1.2 & & 10 & 12.5 & \\
\hline & 6 to 14 & $103(43.1)$ & 21 & 20.3 & & 1 & 1.0 & & 25 & 24.2 & \\
\hline & $\geq 15$ & $56(23.4)$ & 17 & 29.8 & 0.3254 & 1 & 1.8 & 0.9074 & 22 & 39.3 & 0.0015 \\
\hline \multirow[t]{2}{*}{ Use of a protection mask } & Yes & $216(90.4)$ & 51 & 23.6 & & 3 & 1.4 & & 53 & 24.5 & \\
\hline & No & $23(9.6)$ & 4 & 17.4 & 0.5005 & 0 & 0.0 & 0.5695 & 4 & 17.4 & 0.4446 \\
\hline \multirow[t]{2}{*}{ Use of gloves } & Yes & $237(99.1)$ & 55 & 23.2 & & 3 & 1.3 & & 57 & 24.0 & \\
\hline & No & $2(0.8)$ & 0 & 0.0 & 0.4375 & 0 & 0.0 & 0.8728 & 0 & 0.0 & 0.4267 \\
\hline \multirow[t]{2}{*}{ Use of an aspiration system } & Yes & $171(71.5)$ & 33 & 19.3 & & 2 & 1.2 & & 44 & 25.7 & \\
\hline & No & $68(28.5)$ & 22 & 32.3 & 0.0305 & 1 & 1.5 & 0.8504 & 13 & 19.1 & 0.2791 \\
\hline \multirow[t]{8}{*}{ Concomitant disease } & a & $187(78)$ & 39 & 20.8 & 0.1330 & 3 & 1.6 & 0.3580 & 51 & 27.3 & 0.0185 \\
\hline & $b$ & $0(0.0)$ & 0 & 0.0 & - & 0 & 0.0 & - & 0 & 0.0 & - \\
\hline & $c$ & 38 (16) & 14 & 36.8 & 0.0272 & 0 & 0.0 & 0.4485 & 5 & 13.2 & 0.1795 \\
\hline & $d$ & $1(0.4)$ & 0 & 0.0 & - & 0 & 0.0 & - & 0 & 0.0 & - \\
\hline & e & $9(3.7)$ & 2 & 22.2 & 0.9542 & 0 & 0.0 & 0.0870 & 1 & 11.0 & 0.3607 \\
\hline & $b, d$ & $2(0.8)$ & 0 & 0.0 & - & 0 & 0.0 & - & 0 & 0.0 & - \\
\hline & $b, e$ & $1(0.4)$ & 0 & 0.0 & - & 0 & 0.0 & - & 0 & 0.0 & - \\
\hline & d,e & $1(0.4)$ & 0 & 0.0 & - & 0 & 0.0 & - & 0 & 0.0 & - \\
\hline
\end{tabular}


podiatrists with respiratory diseases $(36.8 \%$; $14 / 38)$ compared to those without respiratory diseases $(20.8 \% ; 39 /$ 187) $(p=0.0272)$. No significant differences in the prevalence of MSSA were found for any of the other diseases we examined (i.e., diabetes and immunosuppressive and infectious diseases).

Regarding MRSA, a similar prevalence was found for males $(1.3 \% ; 1 / 83)$ and females $(1.2 \% ; 2 / 156)$, and for participants with different podiatry experience, with a prevalence of $1.2 \%(1 / 80)$ among podiatrists with $\leq 5$ years of experience compared to $1.8 \%$ (1/56) among those with $\geq 15$ years of experience.

The overall prevalence of MRSE was 23.8\% (57/239). Like $S$. aureus, the prevalence of MRSE was significantly greater in men $(33.7 \% ; 28 / 83)$ compared to women (8.6\%; 29/156) $(p=0.0089)$. We observed a significantly higher prevalence among podiatrists aged $\geq 50$ years $(38.5 \%$; $5 / 13)$ compared to those aged $\leq 35$ years $(17.8 \%$; $28 / 157)(p=0.0101)$. Regarding podiatry experience, a higher prevalence was found among podiatrists with $\geq 15$ years of experience $(39.3 \% ; 22 / 56)$ compared to those with $\leq 5$ years of experience $(12.5 \% ; 10 / 80)$ ( $p=$ $0.0015)$. A significantly higher prevalence of MRSE was found among podiatrists who did not have any of the diseases studied $(27.3 \%$; $51 / 187)$ compared to those with a disease $(11.5 \% ; 6 / 52)(p=0.0185)$.

In addition, $7.5 \%(18 / 239)$ of the podiatrists had a cocolonization by both bacteria: $7.1 \%(17 / 239)$ were carriers of MSSA and MRSE while $0.4 \%(1 / 239)$ had MRSA and MRSE. A significantly higher prevalence of cocolonization was found in men $(15.7 \% ; 13 / 83)$ than in women $(3.2 \% ; 5 / 156)(p=0.0005)$. This was also the case for older ( $\geq 50$ years) vs. younger ( $\leq 35$ years) podiatrists, with a prevalence of $30.8 \%(4 / 13)$ and $3.8 \%(6 / 157)$, respectively $(p=0,0006)$. Finally, the prevalence varied with podiatry experience, with those who had $\geq 15$ years of experience having a higher prevalence $(17.9 \%$; $10 / 56)$ than those with $\leq 5$ years of experience $(2.5 \%$; $2 / 80)$ ( $p=$ $0.0026)$. This is similar to what was found for independent colonization by each bacterium.

Tables 2 and 3 show the results of the antimicrobial susceptibility tests for $S$. aureus and S. epidermidis. We found that $84.5 \%(49 / 58)$ of $S$. aureus had resistance to penicillin, $22.4 \%(13 / 58)$ to erythromycin, and $20.7 \%$ $(12 / 58)$ to clindamycin. A $7.2 \%(4 / 55)$ and $0 \%$ of MSSA and MRSA strains showed $\mathrm{iMLS}_{\mathrm{B}}$ phenotype, respectively. In addition, $12.7 \%(7 / 55)$ of the strains were resistant to mupirocin. Only three $S$. aureus isolates (5.2\%; 3/ 58 ) had resistance to methicillin (MRSA), and none were resistant to rifampicin, linezolid, gentamicin, tetracycline, or vancomycin.

Antimicrobial resistance rates among the MRSE strains were higher than among the $S$. aureus strains. The antibiotics with the highest level of resistance were
Table 2 Antimicrobial susceptibility of isolated S. aureus strains

\begin{tabular}{|c|c|c|c|c|c|c|}
\hline \multirow[t]{2}{*}{ Antibiotic } & \multicolumn{3}{|c|}{ Number of strains } & \multicolumn{3}{|l|}{$\%$} \\
\hline & $S$ & I & $\mathrm{R}$ & $S$ & I & $\mathrm{R}$ \\
\hline RIFAMPICIN & 58 & 0 & 0 & 100.0 & 0.0 & 0.0 \\
\hline CHLORAMPHENICOL & 50 & 4 & 4 & 86.2 & 6.9 & 6.9 \\
\hline LINEZOLID & 58 & 0 & 0 & 100.0 & 0.0 & 0.0 \\
\hline GENTAMICIN & 58 & 0 & 0 & 100.0 & 0.0 & 0.0 \\
\hline PENICILLIN & 9 & 0 & 49 & 15.5 & 0.0 & 84.5 \\
\hline COTRIMOXAZOLE & 51 & 2 & 5 & 88.0 & 3.4 & 8.6 \\
\hline CEFOXITIN & 55 & 0 & 3 & 94.8 & 0.0 & 5.2 \\
\hline TETRACYCLINE & 58 & 0 & 0 & 100.0 & 0.0 & 0.0 \\
\hline VANCOMYCIN & 58 & 0 & 0 & 100.0 & 0.0 & 0.0 \\
\hline CIPROFLOXACIN & 54 & 4 & 0 & 93.1 & 6.9 & 0.0 \\
\hline ERYTHROMYCIN & 45 & 0 & 13 & 77.6 & 0.0 & 22.4 \\
\hline CLINDAMYCIN & 46 & 0 & 12 & 79.3 & 0.0 & 20.7 \\
\hline MUPIROCIN & 51 & 0 & 7 & 88.0 & 0.0 & 12.0 \\
\hline
\end{tabular}

ABBREVIATIONS: $S$ susceptible, $I$ intermediate susceptibility, $R$ resistant

penicillin (93.0\%; 53/57), erythromycin (78.9\%; 45/57), and mupirocin $(73.7 \%$; 42/57). A 36.8\% (21/57) were resistant to clindamycin of which a $10.5 \%(6 / 57)$ showed $\mathrm{iMLS}_{\mathrm{B}}$ phenotype. None of the MRSE strains were resistant to linezolid, chloramphenicol or vancomycin.

Table 4 shows the number of antibiotics to which stains of the two species were resistant. We found that 93.0\% (53/57) of MRSE, 33.3\% (1/3) of MRSA, and 20\% $(11 / 55)$ of MSSA strains were resistant to three or more antibiotics.

\section{Discussion}

The prevalence of nasal carriers of $S$. aureus varies greatly between different countries and health professional

Table 3 Antimicrobial susceptibility of isolated MRSE strains

\begin{tabular}{|c|c|c|c|c|c|c|}
\hline \multirow[t]{2}{*}{ Antibiotic } & \multicolumn{3}{|c|}{ Number of strains } & \multicolumn{3}{|l|}{$\%$} \\
\hline & $\bar{S}$ & I & $\mathrm{R}$ & $\bar{S}$ & I & $\mathrm{R}$ \\
\hline RIFAMPICIN & 55 & 0 & 2 & 96.5 & 0.0 & 3.5 \\
\hline CHLORAMPHENICOL & 56 & 1 & 0 & 98.2 & 1.8 & 0.0 \\
\hline LINEZOLID & 57 & 0 & 0 & 100.0 & 0.0 & 0.0 \\
\hline GENTAMICIN & 46 & 0 & 11 & 80.7 & 0.0 & 19.3 \\
\hline PENICILLIN & 4 & 0 & 53 & 7.0 & 0.0 & 93.0 \\
\hline COTRIMOXAZOLE & 44 & 0 & 13 & 77.2 & 0.0 & 22.8 \\
\hline CEFOXITIN & 0 & 0 & 57 & 0.0 & 0.0 & 100.0 \\
\hline TETRACYCLINE & 42 & 0 & 15 & 73.7 & 0.0 & 26.3 \\
\hline VANCOMYCIN & 57 & 0 & 0 & 100.0 & 0.0 & 0.0 \\
\hline CIPROFLOXACIN & 39 & 2 & 16 & 68.4 & 3.5 & 28.1 \\
\hline ERITHROMYCIN & 12 & 0 & 45 & 21.1 & 0.0 & 78.9 \\
\hline CLINDAMYCIN & 36 & 0 & 21 & 63.2 & 0.0 & 36.8 \\
\hline MUPIROCIN & 15 & 0 & 42 & 26.3 & 0.0 & 73.7 \\
\hline
\end{tabular}

ABBREVIATIONS: S susceptible, I intermediate susceptibility, $R$ resistant 
Table 4 Number of antibiotics to which each strain was resistant

\begin{tabular}{|c|c|c|c|c|c|c|c|c|c|}
\hline \multirow[t]{3}{*}{ Strain } & \multirow{3}{*}{$\begin{array}{l}\text { Total } \\
\mathrm{N}\end{array}$} & \multicolumn{8}{|c|}{ Number of antibiotics to which the strains were resistant } \\
\hline & & \multicolumn{2}{|l|}{0} & \multicolumn{2}{|l|}{1} & \multicolumn{2}{|l|}{2} & \multicolumn{2}{|c|}{$\geq 3$} \\
\hline & & $\mathrm{N}$ & $\%$ & $\mathrm{~N}$ & $\%$ & $\mathrm{~N}$ & $\%$ & $\mathrm{~N}$ & $\%$ \\
\hline MSSA & 55 & 7 & 12.7 & 28 & 50.9 & 9 & 16.4 & 11 & 20.0 \\
\hline MRSA & 3 & 0 & 0.0 & 1 & 33.3 & 1 & 33.3 & 1 & 33.3 \\
\hline MRSE & 57 & 0 & 0.0 & 0 & 0 & 4 & 7.0 & 53 & 93.0 \\
\hline
\end{tabular}

ABBREVIATIONS: ATB antibiotic, $O$ ATB resistant to zero antibiotics, 1 ATB resistant to one antibiotic, 2 ATB resistant to two antibiotics, $\geq 3$ ATB resistant to three or more antibiotics

categories; for example, the prevalence of nasal carriers of $S$. aureus among different health personnel has been reported to vary between $22.7 \%$ to $48 \%$ [8-10]. However, in our study, we observed a prevalence of $S$. aureus among podiatrists of $24.3 \%$, which falls within the prevalence range observed in general populationbased studies $(17.8-31.6 \%)[4,6]$.

Regarding the prevalence of MRSA carriers among health workers, previous studies have reported that it varies between $1.5 \%$ and $8.7 \%$ [9, 10, 24, 25], which is higher than the prevalence detected in our study of podiatrists (1.3\%). A review published in 2014 that included 31 studies of different health personnel estimated that there is a mean prevalence of MRSA carriers of $4.0 \%$ in Europe and $6.6 \%$ in the US [26]. In contrast, the prevalence of MRSA among the podiatrists in our study falls within the prevalence range observed in general population-based studies $(0.7$ to $2.1 \%)[5,6,27]$.

Regarding the possible risk factors, although the differences were not significant, the prevalence of $S$. aureus nasal carriage was higher in older clinicials and those with more years of podiatry experience. This shows that the longer the exposure to the infectious agent, the more likely one is to be colonized. There are numerous longitudinal studies that corroborate this observation $[4,28-30]$, such as a study conducted among medical students at the Complutense University of Madrid. This study found the prevalence of $S$. aureus and MRSA colonization to be $26.92 \%$ and $0 \%$, respectively, for students in their third course of study. These values were higher 3 years later, when the students were in their 6th year (46.25\% and $1.25 \%$, respectively). A similar trend was reported by Güçlü et al., who found $13.4 \%$ of preclinical students to be colonized, and $42 \%$ of those in their 5th year of study. In addition, we also observed a higher prevalence among podiatrists who did not use an aspiration system, demonstrating that protective measures are important to avoid the spread of and/or colonization by bacteria.

The S. aureus nasal carrier status is epidemiologically related to the exacerbation of allergic conditions, especially allergic rhinitis. In our study, $34.1 \%$ of the podiatrists with respiratory diseases (such as rhinitis and asthma) were carriers of MSSA, and we found a significant difference with those who did not have respiratory diseases $(p=0.0272)$. This supports the possible association between the presence of such bacteria and allergies.

Regarding antimicrobial susceptibility, the $S$. aureus isolates showed resistance to penicillin (84.5\%), erythromycin (22.4\%), and clindamycin (20.7\%), which is similar to the findings of other recent studies $[5,9,31]$. In our study, $20.6 \%$ of the $S$. aureus isolates had multiresistance (resistance to three or more antibiotics). This is higher than the values reported in previous studies, in which values range from $0.2 \%$ to $7.1 \%[5,32]$.

Among the podiatrists, the prevalence of MRSE was $23.8 \%$, which is similar to the results of a previous study that investigated the prevalence of coagulase-negative Staphylococcus (CoNS) [30] but much higher than the prevalence of $S$. epidermidis reported in students in Vienna, Austria that were 2.5\% [33].

The levels of antibiotic resistance among the MRSE isolates observed in our study are very like those reported in other studies, except for the levels of resistance to erythromycin and mupirocin $(78.9 \%$ and $73.7 \%$, respectively), which were higher than those found in a previous study in Spain [30]. Although mupirocin is the antibiotic of choice for the eradication of Staphylococcus colonization, resistance to this antibiotic has increased in recent years [34, 35]. CoNS has higher levels of resistance to mupirocin than $S$. aureus [36]. These data raise the question of whether the risk of acquisition of mupirocin resistance by $S$. aureus isolates increases in cases of co-colonization with mupirocin-resistant CoNS, especially when $S$. aureus is under selective pressure due to mupirocin administration [37]. Lastly, we found that 93\% of the MRSE strains had resistance to three or more antibiotics, which was much higher than the percentage found among the S. aureus strains (20.7\%).

In addition to the influence of host factors, $S$. aureus colonization is also determined by interactions with the local microbiota. It has been suggested that S. epidermidis in particular has the ability to directly inhibit $S$. aureus colonization. This is done by secreting various substances (including serine protease) that cause the release of host antimicrobial peptides. [38, 39] A recent study showed that there was a lower probability of $S$. aureus colonization in the presence of co-colonization by Staphylococcus lugdunensis due to the production of a "lugdunin" molecule by this bacterium, which acts as an antimicrobial agent, reducing the probability of $S$. aureus colonization. The study showed that, among 187 hospital patients, those who naturally harbored S. lugdunensis in the nose were six times less likely to have $S$. aureus colonization than those who did not carry it [34].

In our study, $7.1 \%$ of subjects were co-colonized by MSSA and MRSE. This is similar to the prevalence 
observed in a 2015 study, which found that co-colonization (with S. aureus and mupirocin-resistant CoNS) occurred at a rate of $6 \%$ [35]. We only observed one case of cocolonization by MRSA and MRSE $(0.4 \%)$ in our study.

Our study explored the prevalence and characteristics of $S$. aureus and S. epidermidis nasal carriage in a representative sample of podiatrists in Spain. To the best of our knowledge, there are no published studies focusing on the prevalence of $S$. aureus and $S$. epidermidis colonization among podiatrists. Thus, this study's findings contribute to our understanding of the carriage status among out-of-hospital health workers and could serve a basis for future studies. However, as our study is a cross-sectional study, we could not establish the prevalence of the different types of carriers: persistent, intermittent, and non-carriers. Thus, it is possible that the prevalence of carriage that we found could vary over time due to the presence of intermittent carriers.

\section{Conclusions}

The prevalence of MSSA, MRSA, MRSE nasal carriage among podiatrists is low compared to other health personnel such as nurses, pediatrician, and even other health workers such as physiotherapists. This suggests that podiatry is not a risk factor for $S$. aureus and $S$. epidermidis colonization.

The risk factors for MSSA nasal colonization were being male, not using an aspiration system at work, and having a respiratory disease. Regarding MRSA, we did not find any significant risk factors. The risk factors for MRSE nasal colonization were being male, being $\geq 50$ years old, having $\geq 15$ years of podiatry experience, and not having any of the diseases examined in this study.

We must highlight the high percentage of mupirocinresistant MRSE strains, as this is the antibiotic of choice for the treatment of nasopharyngeal carriers of Staphylococcus spp.

\section{Additional file}

Additional file 1 Data recovery, S. aureus susceptibility, S.epidermidis susceptibility. (ZIP $55 \mathrm{~kb}$ )

\section{Acknowledgements}

Not applicable.

\section{Availability of data and material}

All data generated or analysed during this study are included in this published article [and its Additional file 1].

\section{Funding}

The authors declare that they have no received funds to make this study.

\section{Authors' contributions}

SB carried out sample collection, processing, and antimicrobial testing. LA participated in the design of the study, draft the manuscript, and performed the statistical analysis. RB and MEL conceived of the study, and participated in its design and coordination and helped to draft the manuscript. MLG and LC participated in the design of the study. DS draft the manuscript. All authors read and approved the final manuscript.

Ethics approval and consent to participate

The study was approved by the Ethical Committee for Clinical Research of the Clinical Trials Coordination Unit at San Carlos Clinical Hospital in Madrid (reference number 16/400-E).

\section{Consent for publication}

Not applicable

\section{Competing interests}

The authors declare that they have no competing interests.

\section{Publisher's Note}

Springer Nature remains neutral with regard to jurisdictional claims in published maps and institutional affiliations.

\section{Author details}

${ }^{1}$ Facultad de Ciencias de la Salud, Universidad Rey Juan Carlos, Madrid, Spain. ${ }^{2}$ Area de Microbiología, Facultad de Medicina, Universidad Complutense de Madrid, Madrid, Spain. ${ }^{3}$ Facultad de Enfermería, Fisioterapia y Podología, Universidad Complutense de Madrid, Madrid, Spain. ${ }^{4}$ Departamento de Medicina, Facultad de Medicina, Universidad Complutense de Madrid, Madrid, Spain.

Received: 8 November 2017 Accepted: 11 February 2018

Published online: 17 February 2018

References

1. Noble WC, Valkenburg HA, Wolters CH. Carriage of Staphylococcus aureus in random samples of a normal population. J Hyg (Lond). 1967; 65(4):567-73. Available from: http://www.ncbi.nlm.nih.gov/pubmed/ 5235259. [cited 2016 Dec 9]

2. Wertheim HFL, Melles DC, Vos MC, Van Leeuwen W, Van Belkum A, Verbrugh HA, et al. The role of nasal carriage in Staphylococcus aureus infections. Lancet Infect Dis. 2005;5(21):751-62. https://doi.org/10.1016/ S1473-3099(05)70295-4. [cited 2016 Nov 13]

3. Eriksen NH, Espersen F, Rosdahl VT, Jensen K. Carriage of Staphylococcus aureus among 104 healthy persons during a 19-month period. Epidemiol Infect [Internet]. 1995;115(1):51-60. Available from: http://www.ncbi.nlm.nih. gov/pubmed/7641838. [cited 2016 Dec 9].

4. Boada A, Almeda J, Grenzner E, Pons-Viqués $M$, Morros $R$, Juvé $R$, et al. Prevalencia de portadores nasales de Staphylococcus aureus y Streptococcus pneumoniae en atención primaria y factores asociados a la colonización. Enferm Infecc Microbiol Clin. 2015;33(7):451-7. https://doi.org/ 10.1016/j.eimc.2014.10.014. Elsevier [cited 2017 Mar 12]

5. den Heijer CD, van Bijnen EM, Paget WJ, Pringle M, Goossens H, Bruggeman CA, et al. Prevalence and resistance of commensal Staphylococcus aureus, including meticillin-resistant $S$ aureus, in nine European countries: a crosssectional study. Lancet Infect Dis. 2013;(5):13, 409-415. https://doi.org/10. 1016/S1473-3099(13)70036-7. [cited 2016 Dec 18]

6. Graham PL, Lin SX, Larson EL. A U.S. population-based survey of Staphylococcus aureus colonization. Ann Intern Med. 2006;144(5):318-25. Available from: http:// www.ncbi.nlm.nih.gov/pubmed/16520472. [cited 2017 Mar 12]

7. DDA S, Milardi LR, Oliveira LL, Oliveira MCM, Almeida SF, Valentim L, et al. Ocorrência de Staphylococcus aureus em fisioterapeutas que atuam em clínicas e hospitais de Governador Valadares Minas Gerais / Staphylococcus aureus occurrence in physical therapists of Governador Valadares Minas Gerais. Fisioter. Bras. Atlântica Editora. 2006;7(1):22-4. Available from: http:// bases.bireme.br/cgi-bin/wxislind.exe/iah/online/?lsisScript=iah/iah.xis\&src= google\&base $=$ LILACS\&lang $=$ p\&nextAction=Ink\&exprSearch $=$ 491331\&indexSearch=ID. [cited 2017 Apr 2]

8. Price JR, Cole K, Bexley A, Kostiou V, Eyre DW, Golubchik T, et al. Transmission of Staphylococcus aureus between health-care workers, the environment, and patients in an intensive care unit: a longitudinal cohort study based on whole-genome sequencing. Lancet Infect Dis. 2017:17(2): 207-14. https://doi.org/10.1016/S1473-3099(16)30413-3. [cited 2017 May 30]

9. Rashid Z, Farzana K, Sattar A, Murtaza G. Prevalence of nasal Staphylococcus aureus and methicillin-resistant Staphylococcus aureus in hospital personnel 
and associated risk factors. Acta Pol Pharm. 2012;69(5):985-91. Available from: http://www.ncbi.nlm.nih.gov/pubmed/23061297. [cited 2017 Sep 7]

10. Garcia C, Acuña-Villaorduña A, Dulanto A, Vandendriessche S, Hallin M, Jacobs J, et al. Dynamics of nasal carriage of methicillin-resistant Staphylococcus aureus among healthcare workers in a tertiary-care hospita in Peru. Eur J Clin Microbiol Infect Dis. 2016;35(1):89-93. https://doi.org/10. 1007/s10096-015-2512-9. [cited 2017 Mar 12]

11. Munckhof WJ, Nimmo GR, Schooneveldt JM, Schlebusch S, Stephens AJ, Williams G, et al. Nasal carriage of Staphylococcus aureus, including community-associated methicillin-resistant strains, in Queensland adults. Clin Microbiol Infect. 2009;15(2):149-55. https://doi.org/10.1111/j.1469-0691. 2008.02652.x. [cited 2014 Mar 2]

12. Mody L, Kauffman CA, Donabedian S, Zervos M, Bradley SF. Epidemiology of Staphylococcus aureus colonization in nursing home residents. Clin Infect Dis. 2008;46(9):1368-73. https://doi.org/10.1086/586751. [cited 2014 Mar 1]

13. Zanger P, Nurjadi D, Gaile M, Gabrysch S, Kremsner PG. Hormonal contraceptive use and persistent Staphylococcus aureus nasal carriage. Clin Infect Dis. 2012; 55(12):1625-32. https://doi.org/10.1093/cid/cis778. [cited 2014 Mar 2]

14. Lipsky BA, Pecoraro RE, Chen MS, Koepsell TD. Factors affecting staphylococcal colonization among NIDDM outpatients. Diabetes Care [Internet]. 1987;10(4):483-486. Available from: http://www.ncbi.nIm.nih.gov/ pubmed/3622205. [cited 2017 Sep 7]

15. Herwaldt LA. Reduction of Staphylococcus aureus nasal carriage and infection in dialysis patients. J Hosp Infect. 1998;40 Suppl B:S13-23. Available from: http://www.ncbi.nlm.nih.gov/pubmed/9777529. [cited 2014 Mar 2]

16. Padoveze MC, de Jesus PR, Blum-Menezes D, Bratfich OJ, Moretti ML. Staphylococcus aureus nasal colonization in HIV outpatients: persistent or transient? Am J Infect Control. 2008;36(3):187-91. https://doi.org/10.1016/j. ajic.2007.05.012. [cited 2014 Mar 2]

17. Herwaldt LA, Cullen JJ, French P, Hu J, Pfaller MA, Wenzel RP, et al. Preoperative risk factors for nasal carriage of Staphylococcus aureus. Infect Control Hosp Epidemiol. 2004;25(6):481-4. https://doi.org/10.1086/502426. [cited 2014 Mar 2]

18. Williams JV, Vowels B, Honig P, Leyden JJ. Staphylococcus aureus isolation from the lesions, the hands, and anterior nares of patients with atopic dermatitis. J Emerg Med. 1999;17(1):207-11. https://doi.org/10.1016/S07364679(98)00151-6. [cited 2016 Dec 4]

19. Proaño DC, Pazmiño FP. Prevalencia de portadores nasales asintomáticos de Staphylococcus aureus meticilino-resistente y su relación con factores de riesgo y protectores en el personal de salud del Hospital General de las Fuerzas Armadas. Rev Mex Patol Clin. 2010;57(4):196-204. Available from: http://www.medigraphic.com/. [cited 2017 Sep 7]

20. Pahissa Berga A. Infecciones producidas por Staphylococcus aureus. 1st ed. Barcelona: Marge Books; 2009. p. 198. Available from: http://www. fundacionio.org/books/books/Infecciones_producidas_por_Staphylococcus_ aureus.html. [cited 2017 Sep 7]

21. Camarena JJ, Sánchez R. INFECCIÓN POR Staphylococcus aureus RESISTENTE A METICILINA. Dep Microbiol Hosp Univ Dr Peset Val [Internet]. 1999; Available from: https://www.seimc.org/contenidos/ccs/revisionestematicas/ bacteriologia/sarm.pdf. [cited 2017 Jul 17].

22. Otto M. Coagulase-negative staphylococci as reservoirs of genes facilitating MRSA infection: Staphylococcal commensal species such as Staphylococcus epidermidis are being recognized as important sources of genes promoting MRSA colonization and virulence. Bioessays. 2013;35(1):4-11. https://doi.org/ 10.1002/bies.201200112. NIH Public Access [cited 2017 Mar 15]

23. Clsi. M100-S24 Performance Standards for Antimicrobial Susceptibility Testing; Twenty-Fourth Informational Supplement An informational supplement for global application developed through the Clinical and Laboratory Standards Institute consensus process. 2014;

24. Akhtar N. Staphylococcal nasal carriage of health care workers. J Coll Physicians Surg Pak. 2010;20(7):439-43. doi: 07.2010/JCPSP.439443. [cited 2017 Jul 23]

25. Saadatian-Elahi M, Tristan A, Laurent F, Rasigade J-P, Bouchiat C, Ranc A-G, et al. Basic Rules of Hygiene Protect Health Care and Lab Workers from Nasal Colonization by Staphylococcus aureus: An International CrossSectional Study. PLoS One. 2013;8(12):e82851. https://doi.org/10.1371/ journal.pone.0082851. [cited 2014 Feb 20]

26. Dancer SJ, Peters C, Schablon A, Nienhaus A, Rabaud C, Berthelot P, et al. Considering the introduction of universal MRSA screening. J Hosp Infect. 2008;69(4):315-20. https://doi.org/10.1016/j.jhin.2008.05.002. BioMed Central [cited 2017 Mar 11]

27. Becker K, Schaumburg F, Fegeler C, Friedrich AW, Köck R. Prevalence of Multiresistant Microorganisms PMM Study. Staphylococcus aureus from the
German general population is highly diverse. Int J Med Microbiol. 2017; 307(1):21-7. https://doi.org/10.1016/j.ijmm.2016.11.007. [cited 2017 Mar 12]

28. Bogaert D, van Belkum A, Sluijter M, Luijendijk A, de Groot R, Rümke $H$, et al. Colonisation by Streptococcus pneumoniae and Staphylococcus aureus in healthy children. Lancet. 2004;363(9424):1871-2. https://doi.org/10.1016/ S0140-6736(04)16357-5. [cited 2017 Mar 12]

29. Güçlü E, Yavuz T, Tokmak A, Behçet M, Karali E, Oztürk O, et al. Nasal carriage of pathogenic bacteria in medical students: effects of clinic exposure on prevalence and antibiotic susceptibility. Eur Arch Otorhinolaryngol. 2007;264(1):85-8. https:// doi.org/10.1007/s00405-006-0160-5. [cited 2017 Jul 17]

30. Rodríguez-Avial C, Alvarez-Novoa A, Losa A, Picazo JJ. [Significant increase in the colonisation of Staphylococcus aureus among medical students during their hospital practices]. Enferm Infecc Microbiol Clin. 2013;31(8):516-519. doi:https://doi.org/10.1016/j.eimc.2012.09.017. [cited 2014 Feb 27]

31. Cuevas Ó, Cercenado E, José Goyanes M, Vindel A, Trincado P, Boquete T, et al. Staphylococcus spp. en España: situación actual y evolución de la resistencia a antimicrobianos (1986-2006). Enferm Infecc Microbiol Clin. 2008;26(5):269-77. https://doi.org/10.1157/13120413. Elsevier [cited 2017 Mar 15]

32. van Bijnen EME, Paget J, de Lange-de Klerk ESM, den Heijer CDJ, Versporten A, Stobberingh EE, et al. Antibiotic Exposure and Other Risk Factors for Antimicrobial Resistance in Nasal Commensal Staphylococcus aureus: An Ecological Study in 8 European Countries. PLoS One. 2015;10(8):e0135094. https://doi.org/10.1371/journal.pone.0135094. Cloeckaert A, editor. John Wiley \& Sons, Inc; [cited 2017 Mar 15]

33. Gualdoni GA, Lingscheid T, Tobudic S, Burgmann H. Low nasal carriage of drug-resistant bacteria among medical students in Vienna. GMS Krankenhhyg Interdiszip. 2012;7(1):Doc04. https://doi.org/10.3205/ dgkh000188. [cited 2014 Feb 11]

34. Zipperer A, Konnerth MC, Laux C, Berscheid A, Janek D, Weidenmaier C, et al. Human commensals producing a novel antibiotic impair pathogen colonization. Nature. 2016;535(7613):511-6. https://doi.org/10.1038/ nature18634. Nature Research [cited 2017 Mar 20]

35. Trouillet-Assant S, Flammier S, Sapin A, Dupieux C, Dumitrescu O, Tristan A, et al. Mupirocin Resistance in Isolates of Staphylococcus spp. from Nasal Swabs in a Tertiary Hospital in France. J Clin Microbiol. 2015;53(8):2713-5. https://doi.org/10. 1128/JCM.00274-15. American Society for Microbiology (ASM) [cited 2017 Apr 3]

36. Kresken M, Hafner D, Schmitz F, Wichelhaus T. Paul-Ehrlich-Society for Chemotherapy. Prevalence of mupirocin resistance in clinical isolates of Staphylococcus Aureus and Staphylococcus Epidermidis: results of the antimicrobial resistance surveillance study of the Paul-Ehrlich-Society for Chemotherapy, 2001. Int J Antimicrob Agents. 2004;23(6):577-81.

37. McConeghy KW, Mikolich DJ, LaPlante KL. Agents for the Decolonization of Methicillin-Resistant Staphylococcus aureus. Pharmacotherapy. 2009;29(3): 263-80. https://doi.org/10.1592/phco.29.3.263. [cited 2017 Apr 24]

38. Sullivan SB, Kamath S, McConville TH, Gray BT, Lowy FD, Gordon PG, et al. Staphylococcus epidermidis Protection Against Staphylococcus aureus Colonization in People Living With Human Immunodeficiency Virus in an Inner-City Outpatient Population: A Cross-Sectional Study. Open forum Infect Dis. 2016;3(4):ofw234. https://doi.org/10.1093/ofid/ofw234. Oxford University Press [cited 2017 Mar 20]

39. Iwase T, Uehara Y, Shinji H, Tajima A, Seo H, Takada K, et al. Staphylococcus epidermidis esp inhibits Staphylococcus aureus biofilm formation and nasal colonization. Nature. 2010;465(7296):346-9. https://doi.org/10.1038/ nature09074. [cited 2017 Mar 20]

\section{Submit your next manuscript to BioMed Central and we will help you at every step:}

- We accept pre-submission inquiries

- Our selector tool helps you to find the most relevant journal

- We provide round the clock customer support

- Convenient online submission

- Thorough peer review

- Inclusion in PubMed and all major indexing services

- Maximum visibility for your research

Submit your manuscript at www.biomedcentral.com/submit 